\title{
PENGAWASAN OTORITAS JASA KEUAGAN TERHADAP SIMPAN PINJAM ONLINE (FINTECH)
}

\author{
Natal Situmorang, Marthin Simangunsong, Debora \\ Fakultas Hukum, Universitas HKBP Nommensen \\ marthinsimangunsong@uhn.ac.id
}

\begin{abstract}
Abstrak
Fintech peer to peer lending atau yang umum dikenal dengan layanan pinjaman online mulai berkembang pada tahun 2016, layanan pinjaman online ini sering digunakan untuk membantu usaha mikro, kecil, menengah(UMKM) lokal. Dalam membahas permasalahan dalam penelitian ini, metode penelitian yang digunakan adalah penelitian hukum normatif yaitu dengan melakukan analisis terhadap permasalahan melalui pendekatan terhadap asas-asas hukum serta mengacu pada kepada aturan hukum yang berlaku yang terdapat pada peraturan perundang-undangan. Hasil penelitian diketahui OJK melakukan pengawasan terhadap Fintech Peer to Peer lending adalah berdasarkan pada Undang-undang No.21 Tahun 2011 tentang OJK secara umum dan secara khusus diatur dalam Peraturan OJK No.77 Tahun 2016 Tentang Layanan Pinjam Meminjam Uang Berbasis Teknologi Informasi. Pemblokiran yang telah dilakukan belum dapat secara efektif mencegah kemunculan pinjaman online ilegal. Salah satu penyebab utamanya karena pembuatan aplikasi pada google bersifat terbuka sehingga perusahaan pinjaman online ilegal dapat membuat kembali layanan serupa meski telah dilakukan pemblokiran berkali-kali.
\end{abstract}

\section{Kata kunci : Pengawasan, Otoritas Jasa Keuangan, Pinjaman Online, Covid-19}

\begin{abstract}
Fintech peer to peer lending or commonly known as online lending services began to develop in 2016, this online loan service is often used to help local micro, small, medium enterprises (MSMEs). Based on OJK Regulation No.77 of 2016 concerning Information Technology-Based Lending and Borrowing Services, all Information Technology-Based Borrowing and Lending services must be registered and obtain a license from the OJK. In discussing the problems in this thesis, the research method used is normative legal research, namely by analyzing the problem through an approach to legal principles and referring to the applicable legal rules contained in statutory regulations. All data in this thesis were collected through library research (library research). Based on the research results, it can be seen that the OJK supervises the Fintech Peer to Peer lending service business based on Law No.21 of 2011 concerning OJK in general and specifically regulated in OJK Regulation No.77 of 2016 concerning Money-Based Lending and Borrowing Services. Information Technology. The blocks that have been carried out have not been able to effectively prevent the emergence of illegal online loans. One of the main reasons is because making applications on Google is open so that illegal online loan companies can re-create similar services even though they have been blocked many times.
\end{abstract}

Keywords: Supervision, Financial Services Authority, Online Loans, Covid-19 
PATIK : JURNAL HUKUM Vol : 09 No. 3, Desember 2020, Hal 147 - 159

\section{Pendahuluan}

Dewasa ini bangsa Indonesia sedang giat melaksanakan pembanguanan disegala bidang. Komponen pembangunan tersebut meliputi pembangunan sumberdaya alam, tenaga kerja dan modal yang satu sama lainnya saling mendunkung sebagai satu kesatuan, sehingga perlu dilaksanakan pembangunan ekonomi nasional yang berkelanjutan dengan berlandaskan demokrasi ekonomi dan prinsip kebersamaan. ${ }^{1}$ Salah satu pengembangan tersebut terletak pada pembangunan sistem keuangan yang berbasis elektonik (finance technology).Kemajuan teknologi menuntut kehidupan masa kini semakin cepat dan praktis. Bermacam jenis aplikasi diciptakan sebagai teknologi yang fungsinya mampu menggantikan berbagai aktivitas manusia. Beberapa tahun belakangan ini bidang finance technology atau Fintech mengalami perkebangan signifikan. Fintech menempatkan teknologi sebagai dasar bisnis dibidang keuangan. Beberapa produk hasil fintech telah dinikmati masyarakat, diantaranya :Mobile Banking, Rekening Ponsel, bahkan e-banking. ${ }^{2}$

Fintech peer to peer lending atau yang umum dikenal dengan layanan pinjaman online ini mulai berkembang pada tahun 2016 dimana pada saat itu layanan pinjaman online lebih sering digunakan untuk membantu usaha mikro, kecil, menengah(UMKM) lokal. Pasalnya pinjaman online ini, bisa memudahkan mereka dalam mengembangkan bisnis tanpa adanya anggunan atau jaminan. Prosesnya yang cepat, juga sangat mempercepat UMKM dalam medapatkan pinjaman.

Namun, seiring munculnya penyedia jasa keuangan berbasis online, yang semakin menjamur ditahun 2018 OJK atau Otoritas Jasa Keuangan mengumumkan bahwa mereka menemukan setidaknya ada 227 perusahaan startup peer to peer lending yang tidak terdaftar di OJK. ${ }^{3}$ Fintech simpan pinjam online yang illegal ini telah banyak meresahkan masyarakat, dimana sistem penagihan dan bunga yang dikenakan pada nasabah yang menungngak tagihan $\mathrm{p}$ embayaran sangat tinggi. Hal tersebut juga sangat disayangkan ketika regulasi yang mengatur tentang Fintech peer to peer lending belum memadai sehingga OJK sebagai lembaga yang berwewenang untuk melakukan pengawasan terhadap lembaga keuangan yang didalamnya termasuk simpan pinjam online dalam melakukan pengawasan dan penindakan tidak dapat dilakukan secara maksimal.

OJK adalah lembaga yang independen dan bebas dari campur tangan pihak lain, yang mempunyai fungsi, tugas dan wewenang pengaturan, pengawasan, pemeriksaan, dan penyidikan terkait kegiatan jasa keuangan bank dan non bank. ${ }^{4}$ Sesuai ketentuan peralihan pasal 55 ayat 1 Undang-Undang No 21 tahun 2011, sejak tanggal 31 Desember 2012, fungsi, tugas, dan wewenang pengaturan dan pengawasan kegiatan jasa keuangan di sektor pasar modal, perasuransian, Dana Pensiun, Lembaga Pembiayaan, dan lembaga jasa keuangan lainnya beralih dari menteri keuangan dan Badan Pengawas Pasar Modal dan Lembaga Keuangan ke OJK.

Adapun beberapa alasan dibentuknya OJK yaitu semakin kompleks dan bervariasinya produk dari jasa keuangan, munculnya gejala konglomerasi perusahaan jasa keuangan, dan globalisasi industri jasa keuangan. Perkembangan yang terjadi sekarang kecenderungan perbankan juga terlibat dalam berbagai transaksi misalkan di pasar modal, industri asuransi, artinya industri finansial kita sudah terjadi konvergensi, dimana antara lembaga keuangan itu kemudian melakukan berbagai sinergi. Bank juga memiliki anak perusahaan

\footnotetext{
${ }^{1}$ Lusiana, Usaha Penenaman Modal di Indonesia, (Jakarta: PT.RajaGrafindo Persada 2012), hlm.1

${ }^{2}$ https://blog.danabijak.com/sejarah-dan-perkembangan-fintech/(diakses pada 25 maret 2020, pukul

$\underline{20.00)}$

${ }^{3} \mathrm{https} / / / \mathrm{www} . c e k a j a . c o m / i n f o / s e j a r a h-m u n c u l n y a-l a y a n a n-p i n j a m a n-o n l i n e-d i-i n d o n e s i a / \quad$ (diakses pada 25 maret 2020, pukul 20.22)

${ }^{4}$ Iskandar Syamsu, Akuntansi Perbankan Dalam Rupiah Dan Valuta Asing,In Media 2013, hlm. 54
} 
termasuk di dalamnya asuransi kemudian lembaga investasi, broker saham, dan lain-lain. Kebutuhannya memang adalah untuk menyatukan pengawasan, karena nanti diharapkan pengawasan ini lebih terkonsolidasi ${ }^{5}$. Berdasarkan pada Rancangan Undang Undang (RUU) OJK, tujuan pendirian OJK secara normatif adalah pertama, meningkatkan dan memelihara kepercayaan publik di bidang jasa keuangan. Kedua, menegakkan peraturan perundang-undnagan di bidang jasa keuangan. Ketiga, meningkatkan pemahaman publik mengenai bidang jasa keuangan. Keempat, melindungi kepentingan konsumen jasa keuangan.

Selain itu tujuan lain OJK dibentuk agar BI fokus kepada pengelolaan moneter ${ }^{6}$ dan tidak perlu mengurusi pengawasan bank karena bank itu merupakan sektor dalam perekonomian. Dalam upaya mewujudkan tujuan, OJK punya kewenangan yang luas yakni membuat peraturan di bidang jasa keuangan, memberi dan mencabut izin persetujuan dan lain-lain, memperoleh laporan periodik dan informasi industri jasa keuangan ${ }^{7}$; mengenakan sanksi administratif, melakukan pemeriksaan, melakukan penyidikan atas pelanggaran UU, memberikan arahan atau perintah tertulis, menunjuk pengelola statuter ${ }^{8}$, mewajibkan pengalihan usaha demi menjaga kepentingan nasabah, mencegah kejahatan dibidang keuangan dan mengatur pengendalian lembaga keuangan.

Dengan adanya OJK diharapkan dapat melakukan pengawasan terhadap lembaga keuangan bank dan non bank serta lembaga jasa keuangan lainnya yang ada di Indonesia. Berdasarkan keputusan menteri keuangan No. Kep.38/MK/IV/I/1972 yang menerbitkan bahwa lembaga-lembaga ini dapat melakukan usaha-usaha sebagai berikut; Pertama, menghimpun dana dengan jalan mengeluarkan surat berharga. Kedua, memberi kredit jangka menengah. Ketiga, mengadakan penyertaan modal yang bersifat sementara. Keempat, bertindak sebagai perantara dari perusahaan indonesia dan badan hukum pemerintah. Kelima, bertindak sebagai perantara dalam mendapatkan tenaga ahli dan memberikan nasihat-nasihat keahlihan. Keenam, melakukan usaha lain di bidang keuangan. ${ }^{9}$ Berdasarkan uraian diatas maka penulis merumuskan masalah sebagai berikut:

1. Bagaimanakah pengawasan OJK terhadap Fintech peer to peer lending (simpan pinjam online).

2. Apakah hambatan yang dialami oleh OJK dalam hal pengawasan terhadap Fintech peer to peer lending (simpan pinjam online)?

\section{Tinjauan Pustaka}

Pembentukan OJK dilator belakangi oleh adanya kebutuhan untuk melakukan penataan kembali lembaga-lembaga yang melaksanakan fungsi pengaturan dan pengawasan di sektor jasa keuangan ${ }^{10}$. Sebelum ada OJK pengawasan industry keuangan

\footnotetext{
${ }^{5}$ Konsolidasi adalah suatu gabungan dua lembaga dan/ atau perusahaan menjadi satu yang memiliki nama baru.

${ }^{6}$ Pengelolaan moneter adalah kebijakan yang diambil oleh bank sentral atau Bank Indonesia dengan tujuan memlihara dan mencapai stabilitas nilai mata uang yang dapat dilakukan antara lain dengan pengendalian jumlah uang yang beredar di masyarakat atau penetapan suku bunga. keuangan.

7 Jasa Keuangan adalah suatu istilah yang untuk merujuk jasa yang disediakan oleh industri

${ }^{8}$ Menurut Undang-Undang No. 21 Tahun 2011 tentang Otoritas Jasa Keuangan dan UndangUndang No. 40 Tahun 2014 tentang perasuransian Pengelola Statuter adalah orang perseorangan atau badan hukum yang ditetapkan OJK untuk melaksanakan kewenangan OJK.

${ }^{9}$ Keputusan menteri keuangan No. Kep. 38/MK/IV/I/1972

${ }^{10}$ Kusumaningtuti S. Soetiono, Mengenal Otoritas Jasa Keuangan dan Industri Jasa Keuangan, (Jakarta: OJK, 2017),hlm15
} 
berjalan terpisah dibawah dua regulator yaitu Bank Indonesia yang mengawasi perbankan dan Bapepam-LK (lembaga Keuangan) yang mengawasi pasar modal dan industri keuangan non-bank ${ }^{11}$.

Otoritas Jasa Keuangan adalah lembaga Negara yang berfungsi menyelenggarakan sistem pengaturan dan pengawasan yang terintegrasi terhadap keseluruhan kegiatan di dalam sektor jasa keuangan. Otoritas Jasa Keuangan merupakan lembaga yang independen dan bebas dari campur tangan dari pihak lain, yang mempunyai fungsi, tugas, dan wewenang pengaturan, pengawasan, pemeriksaan, dan penyidikan. Secara umum dapat dikatakan bahwa Otoritas Jasa Keuangan ini didirkan untuk menggantikan peran BapepamLK untuk melakukan pengawasan secara ketat terhadap lembaga keuangan seperti perbankan, pasar modal, reksadana, perusahaan pembiayaan, dana pension dan asuransi. ${ }^{12}$

Otoritas Jasa Keuangan memiliki arti yang sangat penting tidak hanya bagi masyarakat umum dan pemerintah saja akan tetapi juga bagi dunia usaha (binsis). Bagi masyarakat tentunya dengan adanya OJK akan memberikan perlindungan dan rasa aman atas investasi atau transaksi yang dijalankan lewat lembaga jasa keuangan. Bagi pemerintah adalah akan memberikan kauntungan rasa aman bagi masyarakatnya dan perolehan pendapatan dari perusahaan berupa pajak atau penyedia barang dan jasa yang berkualitas baik. Sedangkan bagi dunia usaha, dngan adanya OJK maka pengelolaannya semakin baik dan perusahaan yang dijalankan semakin makin sehat dan lancar, yang akhirnya akan memperoleh keuntungan yang berlipat. ${ }^{13}$ OJK berkedudukan di ibu kota Negara Kesatuan Republik Indonesia serta dapat mempunyai kantor di dalam dan diluar wilayah negara Kesatuan Negara Republik Indonesiayang dibantuk sesuai dengan kebutuhan. Artinya kehadiran OJK dalam melayani jasa keuangan dapat dilayani di seluruh di tiap-tiap provinsi jika dibutuhkan.

Berdasarkan pada Undang-undang No. 21 Tahun 2011 tentang Otoritas Jasa Keuangan, sejak 31 Desember 2012, fungsi, tugas, dan wewenang pengaturan dan pengawasan kegiatan jasa keuangan di sektor pasar modal, perasuransian, dana pension, Lembaga pembiayaan, dan Lembaga jasa keuangan lainnya beralih dari Menteri Keuangan dan Badan Pengawas Pasar Modal dan lembaga keuangan ke Otoritas Jasa Keuangan dan sejak 31 Desember 2013, fungsi, tugas, daan wewenang pengaturan dan pengawasan kegiatan jasa keuangann disektor perbankan beralih dari bank Indonesia ke Otoritas Jasa Keuangan.

Teknologi Finansial (Tekfin) atau sering disebut juga dengan Financial Technology (Fintech) merupakan industri berbasis teknologi yang melahirkan inovasi di bidang jasa keuangan yang memfasilitasi layanan keuangan (startup) di luar lembaga keuangan konvensional yang mempermudah masyarakat dalam mengakses produk-produk keuangan dan transaksi. Dalam pengertian lebih luas, fintech adalah industri yang terdiri dari perusahaan-perusahaan yang menggunakan teknologi agar sistem keuangan dan penyampaian layanan keuangan lebih efisien. Untuk membantu meningkatkan indeks literasi dan inklusi keuangan di Indonesia, pemerintah mendukung perkembangan teknologi finansial di Indonesia melalui regulasi yang dikeluarkannya. Indonesia sebagai populasi terbesar keempat di dunia dan terbesar di Asia Tenggara menjadikan Indonesia sebagai pangsa besar bagi fintech. Selain itu, pengguna internet di Indonesia pada tahun 2017 mencapai 143.26 juta yang diperkirakan akan terus naik setiap tahunnya. Hal ini dimanfaatkan oleh teknologi finansial sebagai peluang dalam memberikan layanan jasa keuangan berbasis teknologi kepada masyarakat yang lebih praktis dan efisien dalam

\footnotetext{
${ }^{11}$ Mulliaman D Hadad, Buku Saku Otoritas Jasa Keuangan Edisi Ke-2, (Jakarta: OJK, 2015), hlm.2

${ }^{12}$ Kasmir, Dasar-dasar Perbankan, (Jakarta: PT.RajaGrafindo Persada, 2014), hlm.268

13 Ibid,.
} 
melakukan transaksi, seperti mempermudah masyarakat untuk memperoleh modal khususnya di bidang UMKM, dan lainnnya. Perusahaan-perusahaan fintech diharapkan saling berkolaborasi untuk mengembangkan layanan keuangan berbasis teknologi sehingga membantu meningkatkan perekonomian nasional ${ }^{14}$.

Hampir tidak ada yang menyangkal bahwa uang adalah salah satu benda yang berharga bagi manusia. Uang memegang peranan penting dalam kehidupan keluarga, masyarakat dan negara. Uang adalah segala sesuatu yang dapat diterima umum sebagai alat pembayaran dan sebagai alat tukar yang $\operatorname{sah}^{15}$. Dengan berkembangnya jaman proses penggunaan uang semakin berkembangdengan sangat pesat. Lahirnya fintech adalah salah satu perkembangan proses penggunaan uang yang terjadi. Fintech Peer to peer lending atau yang umum dikenal dengan layanan pinjaman online ini ternyata mulai berkembang dan diketahui masyarakat Indonesia pada tahun 2016. Dimana saat itu, layanan pinjaman online, lebih sering digunakan untuk membantu UMKM atau Usaha Mikro, Kecil, dan Menengah lokal. Hukum pinjam meminjam yang berlaku saat ini berkaitan dengan bunga, secara umum memang sudah diatur dalam 1765 Kitab Undang-undang Hukum Perdata yang bunyinya, "Adalah diperbolehkan memperjanjikan bunga atas pinjaman uang atau barang lain yang habis karena pemakaian".

P2P (peer-to-peer) Lending adalah penyelenggaraan layanan jasa keuangan untuk mempertemukan Pemberi Pinjaman dengan Penerima Pinjaman dalam rangka melakukan perjanjian pinjam meminjam melalui sistem elektronik dengan menggunakan jaringan internet. Layanan P2P merupakan penyelenggara badan hukum Indonesia yang menyediakan, mengelola, dan mengoperasikan Layanan Pinjam Meminjam Uang Berbasis Teknologi Informasi. Penerima Pinjaman (borrower) adalah orang dan/atau badan hukum yang mempunyai utang karena perjanjian Layanan Pinjam Meminjam Uang Berbasis Teknologi Informasi. Pemberi Pinjaman (Investor) adalah orang, badan hukum, dan/atau badan usaha yang mempunyai piutang karena perjanjian Layanan Pinjam Meminjam Uang Berbasis Teknologi Informasi ${ }^{16}$.

\section{Metode}

Penelitian yang akan dilakukan adalah penelitian hukum normatif. ${ }^{17}$ Langkah pertama dilakukan adalah penelitian hukum normatif yang didasari pada bahan hukum primer dan sekunder yaitu inventarisasi peraturan-peraturan yang berkaitan dengan pengawasan Otoritas Jasa Keuangan (OJK) terhadap Fintech peer to peer lending (simpan pinjam online). Selain itu, juga dipergunakan bahan-bahan tulisan yang berkaitan dengan pengawasan Otoritas Jasa Keuangan (OJK) terhadap Fintech peer to peer lending (simpan pinjam online) serta hambatan yang dialami oleh Otoritas Jasa Keuangan (OJK) dalam melakukan pengawasan terhadap Fintech peer to peer lending (simpan pinjam online). Tehnik analisa bahan hukum yang digunakan dalam penelitian ini merupakan langkahlangkah yang berkaitan dengan pengolahan bahan-bahan hukum yang dikumpulkan untuk

${ }^{14}$ https://himma.maksi.ugm.ac.id/essay-booklet-the-transformative-power-of-fintech/ (diakses pada 3 juli 2020, pukul 11.39)

${ }^{15}$ Elvis F. Purba, Parulian Simanjuntak, Parada Manik, Bank dan Lembaga Keuangan, (Medan: Multi-Tech, 2003), hlm.3

${ }^{16}$ https://id.wikipedia.org/wiki/P2P Lending\#: :text=P2P\%20(peer\%2Dto\%2Dpeer,penyelenggara $\%$ 20badan\%20hukum\%20Indonesia\%20yang (diakses pada 7 april 2020, pukul 21.11)

${ }^{17}$ Penelitian hukum normatif atau penelitian perpustakaan ini merupakan penelitian yang mengkaji studi dokumen, yakni menggunakan berbagai data sekunder seperti peraturan perundang-undangan, keputusan pengadilan, teori hukum dan dapat berupa pendapat para sarjana. 
meneliti permasalahan seperti yang terdapat dalam rumusan masalah. ${ }^{18}$ Tehnik yang digunakan adalah tehnik analaisis penalaran. Penalaran yang digunakan adalah penalaran induktif yaitu dengan melihat adanya fakta atau gejala yang ada dan kemudian mencoba untuk mengabstraksikan serta mencari prinsip-prinsip yang telah dikuasai untuk membangun suatu hipotesis. ${ }^{19}$ Setelah itu dilakukan interpretasi bahan hukum, kemudian dianalisis sehinggga akan memberikan solusi atas permasalahan dalam penelitian ini.

\section{Pembahasan Dan Hasil}

Kegiatan pinjam meminjam uang, sudah ada sejak dulu. Meski hanya bersifat jangka pendek, pinjaman dana tersebut setidaknya sudah mampu membantu menutupi masalah keuangan, yang sedang kritis. Namun, dengan kemajuan teknologi yang semakin canggih, kini meminjam dana bukanlah sebuah hal yang sulit, karena sudah ada pinjaman online $^{20}$. Fintech P2P lending atau yang umum dikenal dengan layanan pinjaman online ini mulai berkembang dan diketahui masyarakat Indonesia pada tahun 2016. Dimana saat itu, layanan pinjaman online, lebih sering digunakan untuk membantu UMKM (Usaha Mikro, Kecil, dan Menengah) lokal. Pasalnya, pinjaman online untuk UMKM ini, bisa memudahkan mereka dalam mengembangkan bisnis, tanpa adanya agunan atau jaminan. Prosesnya yang cepat, juga sangat mempercepat UMKM dalam mendapatkan pinjaman. Tidak hanya bisa membantu nasabah dalam menyelesaikan masalah finansialnya. Di balik itu, pinjaman online juga dijadikan sebagai tempat alternatif para investor atau para pemberi pinjaman dana, dengan return yang menarik ${ }^{21}$.

Untuk dapat melakukan peminjaman uang secara online kepada para pelaku usaha jasa simpan pinjam online secara umum dilakukan dengan prosedur sebagai berikut :

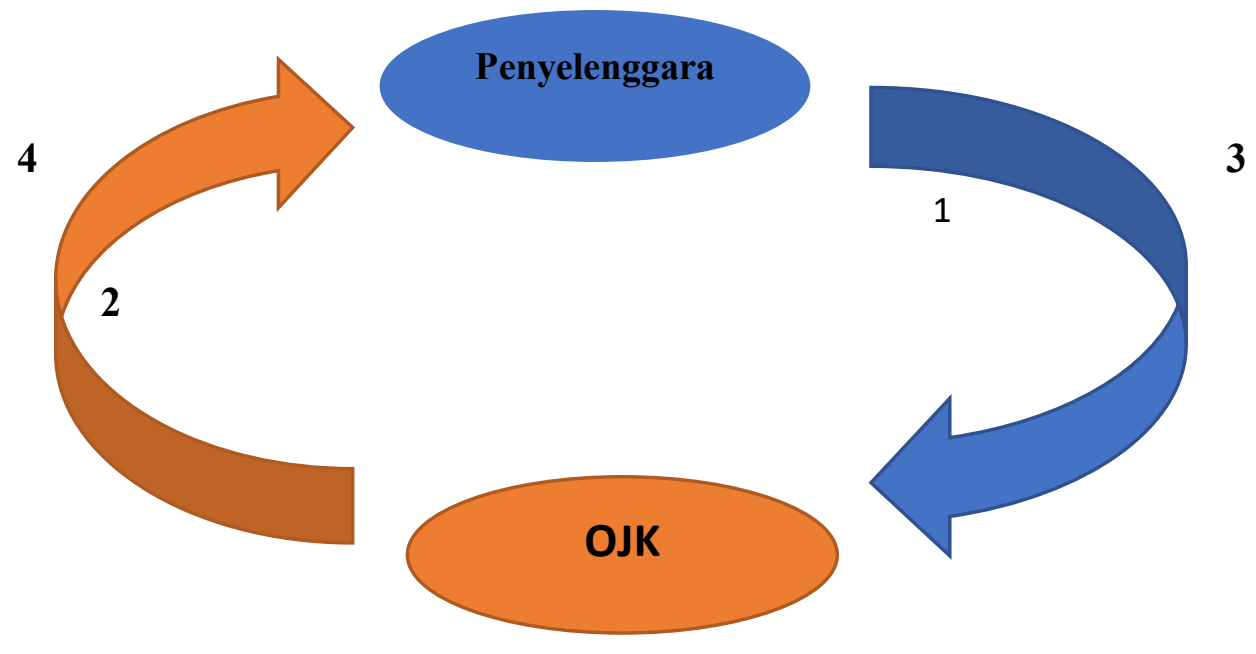

\section{Gambar 1. Skema Mekanisme penyelenggara usaha jasa Fintech Peer To Peer Lending mendapatkan izin ke OJK}

\section{Keterangan :}

1. Penyelengara mengajukan permohonan pendaftaran dan perizinan kepada OJK

\footnotetext{
18 Johny Ibrahim, Teori Dan Metedologi Penelitian Hukum Normatif, (Malang: Bayu Media Publishing, 2006), hlm.297

${ }^{19}$ Peter Mahmud, Penelitian Hmkum, (Jakarta: Kencana, 2006), hlm.43.

${ }^{20} \mathrm{https} / / / \mathrm{www} . c e k a j a . c o m / i n f o / s e j a r a h-m u n c u l n y a-l a y a n a n-p i n j a m a n-o n l i n e-d i-i n d o n e s i a /$ (diakses pada 1 Agustus 2020, pukul 13.50)

${ }^{21}$ Ibid,.
} 
2. OJK menetapkan persetujuan pendaftaran penyelenggara paling lama 10 hari sejak dokumen permohonan pendaftaran diterima

3. Penyelenggara yang sudah terdaftar di OJK, wajib mengajukan permohonan izin sebagai penyelenggara dalam jangka waktu paling lama 1 Tahun

4. OJK memberikan persetujuan atau penolakan atas permohonan perizinan paling lama 20 hari kerja sejak dokumen permohonan izin diterima, dan apabila lewat 20 hari maka perizinan secara otomatis berlaku.

Prosedur mendapatkan izin untuk usaha jasa simpan pinjam online diatur dalam pasal 9 sampai dengan pasal 11 peraturan OJK No. 77 Tahun 2016 Tentang Layanan Pinjam Meminjam Uang Berbasis Teknologi Informasi. Berkembangnya situs fintech di Indonesia tak lepas dari tingginya minat masyarakat akan pinjaman online langsung cair yang memberikan beragam penawaran menarik yang memikat. Jadi tak heran kalau keberadaan pinjaman online bukanlah hal yang asing lagi di mata masyarakat. Fintech Peer to Peer Lending memiliki kelebihan dan kelemahan.

Indonesia di hadapkan dengan banyak persoalan dalam aspek ekonomi akibat dari pandemi Covid-19. Kondisi ekonomi di Indonesia nampak memprihatinkan, ekonomi secara global 2020 diperkirakan bisa jatuh seperti depresi 1930, bukan lagi seperti tahun 2008 atau 1998. Kondisi ini juga memicu penurunan perdagangan bahkan perdagangan internasional. Di Indonesia sendiri berbagai sektor harus terkendala dalam proses operasi, seperti pabrik-pabrik yang harus menghentikan proses operasi karena kondisi tidak memungkinkan ${ }^{22}$

Menteri Perencanaan Pembangunan Nasional (PPN)/Kepala Bappenas Suharso Monoarfa pun memaparkan, di Indonesia jumlah angka pengangguran meningkat 3,7 juta orang akibat pandemi ${ }^{23}$. Kementerian Ketenagakerjaan melaporkan, hingga 12 Mei 2020 jumlah tenaga kerja yang dirumahkan maupun terkena Pemutusan Hubungan Kerja ( PHK) mencapai 1.722 .958 orang $^{24}$. Dengan keadaan ini Pinjaman dari fintech pun dianggap lebih pasti ketika ada kebutuhan mendesak. Ini dibandingkannya dengan meminjam ke orang lain secara konvensional ${ }^{25}$.

Namun yang menjadi kekhawatiran adalah bahwa masih banyak usaha jasa simpan pinjam online yang belum terdaftar atau masih illegal dan melakukan praktek yang dapat merugikan masyarakat. Pinjaman ini semakin merajalela apalagi di tengah pandemi corona yang menghantam ekonomi nasional. Tak sedikit masyarakat Indonesia yang harus rela penghasilannya berkurang atau bahkan kehilangan pekerjaan. Sehingga situasi ini banyak dimanfaatkan oleh mereka yang butuh kucuran dana, lewat perusahaan pembiayaan seperti pinjaman online ${ }^{26}$. Situasi seperti inilah yang akhirnya dimanfaatkan oleh pinjaman online ilegal untuk mengelabui korbannya ${ }^{27}$. Statistik Fintech Lending data Desember 2019 perusahaan Fintech terdaftar/berizin sesuai ketentuan peraturan OJK No. 77 Tahun 2016 terdapat sebanyak 164 perusahaan dengan aset Fintech sebesar Rp.

\footnotetext{
${ }^{22}$ https://www.uii.ac.id/ekonomi-di-masa-pandemi-covid-19/ (diakses pada 1 Agustus 2020, pukul $\underline{18.43)}$

${ }^{23}$ https://money.kompas.com/read/2020/07/28/144900726/akibat-covid-19-jumlah-pengangguran-ribertambah-3-7-juta (diakses pada 1 Agustus 2020, pukul 18.59)

${ }^{24}$ https://money.kompas.com/read/2020/05/12/220000926/kemenaker-pekerja-yang-di-phk-dandirumahkan-capai-17-juta (diakses pada 1 Agustus 2020, pukul 19.04)

${ }^{25} \mathrm{https}$ ://www.liputan6.com/tekno/read/3629456/alasan-masyarakat-lebih-suka-pinjam-uang-kestartup-fintech (diakses pada 1 Agustus 2020, pukul 18.51)

${ }^{26}$ Ibid,

${ }^{27}$ Ibid,.
} 
3.036.264.224.429,00 28 , sedangkan pada Mei 2020 perusahaan Fintech terdaftar/berizin sesuai ketentuan peraturan OJK No. 77 Tahun 2016 terdapat sebanyak 161 perusahaan ${ }^{29}$. Jumlah akumulasi penyaluran pinjaman adalah sebanyak Rp. 109.175,31 Miliar $^{30}$. Jumlah tersebut sangat fantastis, menunjukkan bahwa masyarakat Indonesia pada kondisi pandemi Covid-19 ini banyak menggunakan jasa pinjaman online.

Usaha jasa simpan pinjam online adalah salah satu jnis usaha di bidang jasa keuangan yang diawasi oleh OJK berdasarkan Undang-undang ini sebagai dasar utama yang kemudian lebih khusus diatur dalam Peraturan OJK No.77 Tahun 2016 Tentang Layanan Pinjam Meminjam Uang Berbasis Teknologi Informasi. OJK sebagai lembaga yang independen melakukan pengawasan terhadap usaha jasa Fintech Peer to Peer lending adalah dengan membatasi segala kententuan yang akan dilakukan oleh para pelaku usaha jasa Fintech Peer to Peer lending, sehingga tidak merugikan masyarakat sebagai konsumen atau pengguna jasa layanan Fintech Peer to Peer lending. Ketentuan-ketentuan pembatasan tersebut diatur dalam Peraturan OJK No.77 Tahun 2016 Tentang Layanan Pinjam Meminjam Uang Berbasis Teknologi Informasi. Pengawasan juga lebih terkontrol dengan adanya kententuan yang ada dalam : Pasal 9 ayat (1) dimana berbunyi:"Penyelenggara yang telah terdaftar wajib melakukan laporan secara berkala setiap (3) bulan untuk periode yang berakhir pada tanggal 31 Maret, 30 Juni, 39 September, dan 31 Desember kepada OJK ${ }^{31}$........."

Pada pasal 44,45 dan 46 POJK No.77 Tahun 2016 mengatur tentang laporan berkala. Kewajiban para pelaku usaha jasa simpan pinjam online dalam memberikan laporan secara rutin ke OJK akan berdampak pada pengawasan yang akan semakin intens dan sistematis dapat dilakukan dengan baik dan efektif. Dengan adanya ketentuanketentuan tersebut, maka akan terlihat apabila ada perilaku menyimpang yang dilakukan oleh para pelaku usaha jasa layanan Fintech Peer to Peer lending dan dapat segera ditindak sesuai ketentuan yang berlaku ataupun dikenakan sanksi sesuai dengan pasal 47 Peraturan OJK No.77 Tahun 2016 Tentang Layanan Pinjam Meminjam Uang Berbasis Teknologi Informasi atau peraturan perundang-undangan yang lain yang mengikat tentang perbuatan menyimpang tersebut secara pidana maupun secara perdata.

Seriusnya dan parahnya masalah pinjaman online ilegal membuat OJK menerjunkan Satgas Investasi atau lengkapnya disebut "Satuan Tugas Penanganan Dugaan Tindakan Melawan Hukum di Bidang Penghimpunan Dana Masyarakat dan Pengelolaan Investasi". Satgas tersebut dibentuk berdasarkan Keputusan Dewan Komisioner Otoritas Jasa Keuangan Nomor : 01/KDK.01/2016 tanggal 1 Januari 2016 dan merupakan hasil kerjasama beberapa instansi terkait, yang meliputi :Otoritas Jasa Keuangan, Kementerian Perdagangan Republik Indonesia, Badan Koordinasi Penanaman Modal, Kementerian Koperasi dan Usaha Kecil dan Menengah Republik Indonesia, Kementerian Komunikasi dan Informasi Republik Indonesia, Kejaksaan Republik Indonesia dan Kepolisian Negara Republik Indonesia. ${ }^{32}$

Pengawasan juga dilakukan dengan menerima laporan atau aduan dari masyarakat ke OJK maupun ke Satgas Investasi OJK.

${ }^{28}$ https://www.ojk.go.id/id/kanal/iknb/data-dan-statistik/fintech/Pages/Statistik-Fintech-LendingPeriode-Desember-2019.aspx (diakses pada 30 Juli 2020, pukul 21.16)

${ }^{29}$ https://www.ojk.go.id/id/kanal/iknb/data-dan-statistik/fintech/Pages/-Statistik-Fintech-Lending$\underline{\text { Periode-Mei-2020.aspx (diakses pada } 30 \text { Juli 2020, pukul 20.49) }}$

${ }^{30}$ Ibid,. Informasi

${ }^{31}$ POJK No.77 Tahun 2016 Tentang Layanan Pinjam Meminjam Uang Berbasis Teknologi

${ }^{32}$ https://duwitmu.com/pinjaman-online/cara-melaporkan-pinjaman-online-ilegal-ke-ojk/amp/ (diakses pada 1 Agustus 2020, pukul 23.42) 


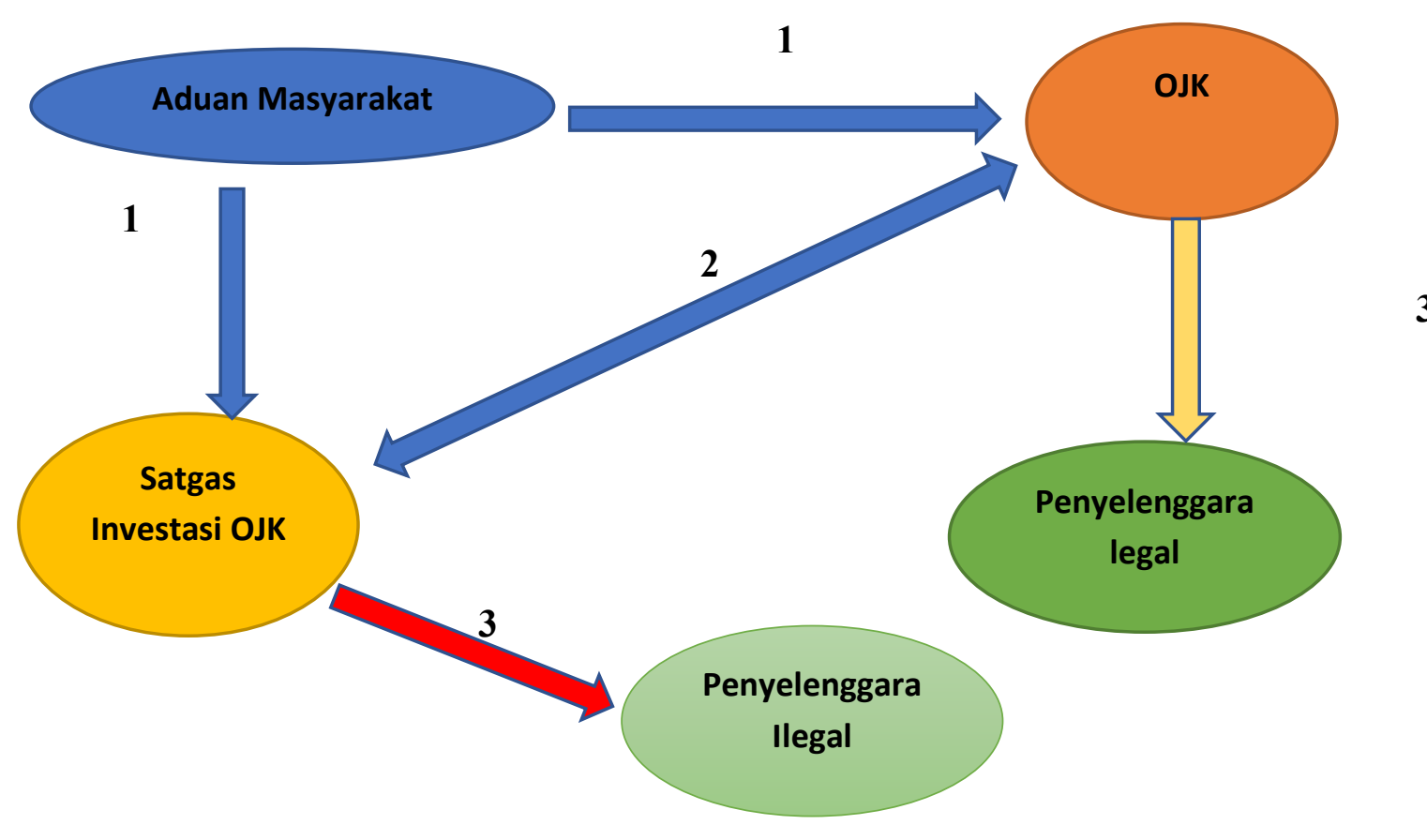

\section{Keterangan:}

1. Masyarakat melakukan pengaduan kepada OJK atau kepada Satgas Investasi OJK.

a. OJK memiliki bagian khusus Perlindungan Konsumen, yang menangani dari pengaduan konsumen termasuk soal pinjaman online, yang mana konsumen pinjaman dapat menyampaikan permintaan informasi atau pengaduan kepada OJK melalui sarana yang meliputi :

Surat Tertulis dari konsumen ditujukan: Anggota Dewan Komisioner Otoritas Jasa Keuangan, Bidang Edukasi dan Perlindungan Konsumen, Menara Radius Prawiro, Lantai 2 , Komplek Perkantoran Bank Indonesia, Jl. MH. Thamrin No. 2 Jakarta Pusat 10350. Telepon : 157 Jam operasional : Senin - Jumat, Jam 08.00 - 17.00 WIB. Email: Permintaan informasi dan pengaduan disampaikan email: konsumen@ojk.go.id Form Pengaduan Online: Masyarakat dapat mengirimkan pengaduan dalam form elektronik yang tersedia di http://konsumen.ojk.go.id/FormPengaduan. ${ }^{33}$

b. Di dalam OJK juga terdapat Satgas Investasi, yang melakukan penutupan atas aktivitas pinjaman atau investasi yang ilegal. Penutupan Fintech ilegal dilakukan oleh Satgas Investasi, termasuk menutup aplikasi fintech. Laporan atau aduan dapat dilakukan ke Kontak Satgas Investasi call center: (021) 1500 655 atau email: waspadainvestasi@ojk.go.id atau Satgas Waspada Investasi, Gedung Soemitro Djojohadikusumo, Jalan Lapangan Banteng Timur No. 2-4 10710 DKI Jakarta Indonesia. ${ }^{34}$

2. OJK dan Satgas Investasi saling berkoordinasi untuk melakukan penelitian terhadap laporan atau aduan masyarakat

3. OJK mengawasi dan menindak penyelenggara simpan pinjam online yang terdaftar di OJK, sedangkan Satgas Investasi Menindak penyelenggara simpan pinjam online yang illegal atau belum terdaftar dan mendapatkan izin dari OJK.

\footnotetext{
${ }^{33}$ Ibid,. (diakses pada 2 Agustus 2020, pukul 00.24)

${ }^{34}$ Ibid,. (diakses pada 2 Agustus 2020, pukul 00.28)
} 
Pinjaman online adalah fasilitas pinjaman uang oleh penyedia jasa keuangan yang beroperasi secara online ${ }^{35}$. Mengacu pada data OJK, jumlah perusahaan pemberi pinjaman atau kredit online pada tahun 2017 mencapai 100.940 dengan dana pinjaman senilai 2,56 triliun $^{36}$. Pada April 2020, setidaknya sudah ada 81 jasa pinjaman online ilegal yang ditindak oleh tim SWI (Satgas Waspada Investasi) $\mathrm{OJK}^{37}$. Pada tahun 2020 ini dilansir dari laman resmi OJK, terdapat 125 jasa pinjaman online yang illegal.

Maraknya perusahaan pinjman online yang beroperasi di Indonesia dan belum terdaftar atau ilegal pada OJK akan membuat jatuhnya banyak korban, hal tersebut terjadi karena pinjaman online ilegal tidak dalam pengawasan sehingga tidak tunduk pada aturan apapun. Selain itu adanya resiko terhadap pelanggaran seperti adanya bunga pinjaman yang tinggi, pencurian data pribadi hingga penagihan yang dilakukan secara intimidatif sangat rentan dapat menimpa masyarakat sebagai konsumen dari pinjaman online tersebut. Hal ini akan semakin diperparah dengan kurangnya atau masih rendahnya pemahaman masyarakat mengenai pinjaman online itu sendiri. Sehingga dengan mudah masyarakat akan tergiur dengan kemudahan pinjaman dana dan menjadi tidak teliti serta tidak mempertimbangkan manfaat sehingga tanpa menyadari risiko yang akan didapat ${ }^{38}$.

Adanya keuntungan besar dalam menjalankan kegiatan pinjaman online secara ilegal salah satunya menjadi penyebab para pelaku untuk tidak mendaftarkan pada OJK, oleh karenanya keberadaan pinjaman online ilegal tersebut menjadi concern bersama dan pemberantasan dilakukan melalui satgas waspada investasi dimana OJK sebagai koordinatornya. Satgas Waspada Investasi yang merupakan gabungan lembaga dan instansi yang bertugas untuk memonitor dan melakukan tindakan preventif baik terhadap investasi maupun pinjaman online ilegal ${ }^{39}$.

Terhadap pinjaman online legal atau pinjaman online yang terdaftar pada OJK,maka perusahaan tersebut harus memenuhi semua aturan yang berlaku terkait jasa layanan pinjam meminjam online. Batasan yang diberikan oleh OJK terhadap pinjaman online legal hanya pada mikrofon, lokasi dan kamera yang dibutuhkan untuk kepentingan e-Know Your Customer, apabila pinjaman online legal terbukti melakukan tindakan yang melanggar peraturan maka OJK akan langsung menindak tegas dengan pengenaan sanksi hingga pada pencabutan izin usaha berdasarkan ketentuan POJK No.77, sedangkan terhadap pinjaman online ilegal yang tidak terawasi tersebut dapat dengan mudah melakukan pelanggaran-pelanggaran yang dapat merugikan peminjamnya.

Berdasarkan hasil wawancara pada Kantor OJK Regional 8 Bali dan Nusa Tenggara dengan Dewan Komisioner Bidang Edukasi dan Perlindungan Konsumen, menyatakan bahwa OJK melalui Satgas Waspada Investasi telah melakukan pemblokiran terhadap pinjaman-pinjaman online ilegal, namun meski telah dilakukan pemblokiran layanan pinjaman online illegal tersebut masih mempunyai celah untuk tetap dapat membuat aplikasi yang baru dengan nama yang baru, sehingga layanan pinjaman online illegal masih dengan mudah didapati kembali pada toko-toko aplikasi pada website eperti pada google store maupun apple store. Tindakan pemblokiran yang selama ini telah dilakukan belum dapat secara efektif mencegah kemunculan pinjaman online illegal tersebut. Hal ini dapat disebabkan karena

${ }^{35}$ https://www.online-pajak.com/pinjaman-online (diakses pada 30 Juli 2020, pukul 20.04)

36 Ibid,

$37 \mathrm{https} / /$ www.cekaja.com/kredit/news/178693-daftar-pinjaman-online-ilegal-terbaru.html (diakses pada 30 Juli 2020 , pukul 20.16)

38 https://ojs.unud.ac.id/index.php/ActaComitas/article/view/52418/34449 (diakses pada 30 Juli 2020, pukul 00.26 
kemudahan bagi perusahaan pinjaman online illegal untuk membuat kembali layanan serupa meski telah dilakukan pemblokiran berkali-kali.

Aplikasi pinjaman online illegal dapat dengan mudah diakses oleh masyarakat karena masyarakat hanya perlu mendownload aplikasi pinjaman online yang diinginkan melalui app store yang ada di hand phone untuk selanjutnya mengikuti syarat yang ditentukan dan selanjutnya dapat melakukan pinjaman uang. Begitu mudahnya melakukan pinjaman uang tanpa harus pergi atau menghabiskan waktu ke bank. Selain itu OJK melalui satgas waspada investasi juga telah meminta kepada pihak google untuk mencegah munculnya domain maupun aplikasi pinjaman online ilegal. Dilakukan dengan cara OJK memberikan daftar pinjaman online yang legal kepada pihak google dengan begitu google dapat melarang aplikasi atau domain fintech pinjaman yang tidak terdaftar pada OJK. Namun, pihak google mengatakan bahwa mereka tidak bisa mendeteksi hal tersebut dikarenakan pembuatan domain atau aplikasi pada google bersifat terbuka. Oleh karenanya, google hanya dapat membantu mengawasi melalui pantauan penawaran pinjaman online illegal di internet. ${ }^{40}$

Kendala yang dialami OJK adalah pemblokiran yang telah dilakukan belum dapat secara efektif mencegah kemunculan pinjaman online ilegal. Salah satu penyebabnya karena pembuatan aplikasi pada google bersifat terbuka sehingga perusahaan pinjaman online ilegal dapat membuat kembali layanan serupa meski telah dilakukan pemblokiran berkali-kali ${ }^{41}$.Dengan kondisi pandemi Covid-19 saat ini OJK pasti akan sangat tidak efektif dalam melakukan fungsi pengawasan terhadap layanan jasa simpan pinjam online, sementara dengan kondisi Pandemi ini jenis usaha jasa layanan simpan pinjam online ini semakin merajalela dengan memanfaatkan situasi dengan kondisi ekonomi yang sulit. Tentu kejadian seorang supir angkot di Padang, Sumatera Barat tewas gantung diri lantaran diduga terlilit utang dari aplikasi pinjaman online ${ }^{42}$, merupakan berita yang tidak terlupakan hingga saat ini. mekanisme penagihan dan sistem bunga yang tidak normal adalah pemicu utama kejadian tersebut. dipastikan bahwa pelaku usaha jasa layanan simpan pinjam online tersebut tidak legal atau tidak terdaftar ke OJK. Masih banyak kasuskasus yang terjadi dan meresahkan masyarakat akibat perilaku menyimpang yang dilakukan oleh pelaku usaha layanan simpan pinjam online bahkan tidak menempuh jalur hukum sebgai mana mestinya karena para korban merasa malu karena terlilit hutang dan takut akibat intimidasi dari para penagih dari pelaku usaha jasa simpan pinjam online

\section{Kesimpulan Dan Saran}

OJK sebagai lembaga yang independen melakukan pengawasan terhadap usaha jasa Fintech Peer to Peer lending adalah berdasarkan pada Undang-undang No.21 Tahun 2011 tentang OJK secara umum dan secara khusus diatur dalam Peraturan OJK No.77 Tahun 2016 Tentang Layanan Pinjam Meminjam Uang Berbasis Teknologi Informasi. Kemudian dengan ketentuan pasal 9, 44,45 dan 46 pengawasan dilakukan dengan meneliti laporan yang dilakukan oleh pelaku usaha jasa simpan pinjam online secara rutin ke OJK. OJK juga menerjunkan Satgas Investasi atau lengkapnya disebut "Satuan Tugas Penanganan Dugaan Tindakan Melawan Hukum di Bidang Penghimpunan Dana Masyarakat dan Pengelolaan Investasi” Pengawasan juga dilakukan dengan menerima laporan atau aduan

\footnotetext{
${ }^{40}$ Ibid,.

${ }^{41}$ https://ojs.unud.ac.id/index.php/ActaComitas/article/view/52418 (diakses pada 30 Juli 2020, pukul $\underline{23.18)}$

${ }^{42}$ https://regional.kompas.com/read/2020/02/14/22103511/sopir-angkot-bunuh-diri-karena-terlilitutang-di-pinjaman-online-ini-kata?page=all (diakses pada 30 Juli 2020, pukul 00.56)
} 
dari masyrakat baik kepada OJK melalui surat, email: konsumen@ojk.go.id, telepon kekontak OJK 157 dan/atau mengirimkan pengaduan dalam format elektronik yang tersedia di http://konsumen.ojk.go.id/, maupun kepada Satgas Investasi OJK melalui surat, menghubungi call center dan/atau email: waspadainvestasi@ojk.go.id dan laporan tersebut akan di teliti dan dapat ditindak apabila terjadi penyimpangan atau pelanggaran hukum sesui dengan Undang-undang No.21 Tahun 2011 tentang OJK dan Peraturan OJK No.77 Tahun 2016 Tentang Layanan Pinjam Meminjam Uang Berbasis Teknologi Informasi dan dapat diproses baik secara perdata maupun secara pidana. Perlunya dibuat UU baru tentang Fintech Peer To Peer Lending supaya masyarakat tidak kebingungan dengan yang dimaksud dengan Fintech Peer To Peer Lending dan penegakan hukumnya dapat dilakukan dengan lebih baik

Kendala yang dialami OJK dalam mengawasi usaha jasa simpan pinjam online saat ini adalah untuk melakukan pengawasan dengan kondisi pandemi Covid-19 menjadi terbatasi, sehingga pengawasan tidak dapat dilakukan secara maksimal. Pemblokiran yang telah dilakukan belum dapat secara efektif mencegah kemunculan pinjaman online ilegal. Salah satu penyebabnya karena pembuatan aplikasi pada google bersifat terbuka sehingga perusahaan pinjaman online ilegal dapat membuat kembali layanan serupa meski telah dilakukan pemblokiran berkali-kali. Perlunya dibuat organ penelusuran terhadap usaha jasa simpan pinjam online supaya yang tidak terdaftar atau illegal dapat di monitor dan segera ditindak sebagai upaya preventif untuk mencegah kerugian dan leresahan terhadap masyarakat.

\section{DAFTAR PUSTAKA}

\section{Buku dan Jurnal}

Budi Santoso, Totok dan Nuritmo. Bank dan Lembaga Kaeuangan Lain. Penerbit Salemba Empat. Jakarta. 2014.

Kasmir. Bank dan lembaga keuangan lainnya. PenerbitPT RajaGrafindo

Persada. Jakarta. 2012.

--------.Dasar-dasar Perbankan. Penerbit PT RajaGrafindo Persada. Jakarta. 2014.

Lusiana. Usaha Penenaman Modal di Indonesia. Penerbit PT.RajaGrafindo Persada Jakarta. 2012.

Muhammad, Abdulkadir. Hukum Perdata Indonesia. Penerbit PT Citra

Aditya Bakti. Bandung. 2012.

Syamsu, Iskandar. Akuntansi Perbankan Dalam Rupiah Dan Valuta Asing.

Penerbit In Media. 2013.

Soetiono, Kusumaningtuti S. Mengenal Otoritas Jasa Keuangan dan Industri

Jasa Keuangan. Penerbit OJK. Jakarta. 2017.

Tumanggor, M.S. Pengenalan Otoritas Jasa Keuangan pasar uang, Pasar

Modal, dan Penanaman Modal. Penerbit F Media Jakarta. 2014.

Sirait, T.N, \& Simangungsong, J.B. (2020). ANALISIS YURIDIS PELAKSANAAN TUGAS POKOK PENGELOLA DOMAIN INTERNET INDONESIA.

Nommensen Journal of Legal Opinion, 1(01), 53-63. https://doi.org/10.51622/njlo.v1i01.38

\section{Peraturan Perundang-Undangan}


Undang-Undang No. 10 Tahun 1998 Tentang Perbankan

Undang-Undang No. 2 Tahun 1992 Tentang Usaha Peransuransian

Undang-Undang No. 11 Tahun 1992 Tentang Peraturan Kerja Dana Pensiun

Undang-Undang No. 8 Tahun 1995 Tentang Pasar Modal

Undang-Undang No. 21 Tahun 2011 Tentang Otoritas Jasa Keuangan

Undang-Undang No. 40 Tahun 2014 Tentang Perasuransian

Peraturan Pemerintah Pengganti Undang-Undang Republik Indonesia No.4 Tahun 2008

Peraturan Presiden Republik Indonesia No. 9 Tahun 2009

Keputusan menteri keuangan No. Kep. 38/MK/IV/I/1972

Peraturan OJK No.77 Tahun 2016 Tentang Layanan Pinjam Meminjam Uang Berbasis Teknologi Informasi

\section{Website}

https://blog.danabijak.com/sejarah-dan-perkembangan-fintech/

https://www.cekaja.com/info/sejarah-munculnya-layanan-pinjaman-online-di-

indonesia/

https://uangteman.com/blog/blog/hukum-pinjam-meminjamonline/

https://id.wikipedia.org/wiki/Teknologi_finansial

https://id.wikipedia.org/wiki/P2P Lending\#: : text=P2P\%20(peer\%2Dto\%2Dpeer,

penyelenggara $\% 20$ badan $\% 20$ hukum $\% 20$ Indonesia $\% 20$ yang

https://koinworks.com/blog/definisi-fintech/

https://id.wikipedia.org/wiki/P2P_Lending\#Cara_Kerja_P2P_Lending

https://id.wikipedia.org/wiki/P2P_Lending\#Peminjam

https://id.wikipedia.org/wiki/P2P Lending\#Pendana

https://id.wikipedia.org/wiki/P2P Lending\#OJK Menutup 182 P2P Tidak Berijin,

https://id.wikipedia.org/wiki/P2P_Lending\#Manfaat_dan_Resiko

https://id.wikipedia.org/wiki/P2P_Lending\#Penyelenggara_P2P

https://www.cekaja.com/info/sejarah-munculnya-layanan-pinjaman-online-di- indonesia/

https://www.liputan6.com/bisnis/read/3867964/ini-kelebihan-dan-kekurangan- pinjamanonline-langsung-cair

https://www.uii.ac.id/ekonomi-di-masa-pandemi-covid-19/

https://money.kompas.com/read/2020/07/28/144900726/akibat-covid-19-jumlah-

pengangguran-ri-bertambah-3-7-juta

https://www.liputan6.com/tekno/read/3629456/alasan-masyarakat-lebih-suka- pinjamuang-ke-startup-fintech

https://www.ojk.go.id/id/kanal/iknb/data-dan-statistik/fintech/Pages/Statistik-Fintech-

Lending-Periode-Desember-2019.aspx

https://www.ojk.go.id/id/kanal/iknb/data-dan-statistik/fintech/Pages/-Statistik-Fintech-

Lending-Periode-Mei-2020.aspx

https://www.online-pajak.com/pinjaman-online

https://www.cekaja.com/kredit/news/178693-daftar-pinjaman-online-ilegal-terbaru.html

https://ojs.unud.ac.id/index.php/ActaComitas/article/view/52418/34449

https://ojs.unud.ac.id/index.php/ActaComitas/article/view/52418

https://regional.kompas.com/read/2020/02/14/22103511/sopir-angkot-bunuh-diri-karena-

terlilit-utang-di-pinjaman-online-ini-kata?page $=$ all

https:/himma.maksi.ugm.ac.id/essay-booklet-the-transformative-power-of-fintech/

https://sevima.com/cara-mudah-membuat-jurnal-ilmiah-yang-benar-dan-baik/

https://id.wikipedia.org/wiki/Jurnal_ilmiah 